\title{
Ulayat Right of Customary Law Community
}

\author{
Adonia Ivonne Laturette \\ Faculty of Law, Pattimura University \\ Jln. Ir. M. Putuhena Kampus Poka, Ambon, 97233, Indonesia \\ Tel./Fax: +62-911-3825204, E-mail: laturettedony@yahoo.com
}

\begin{abstract}
Ulayat right is a right that is given a magical aspect as a threatening force and can sanction as a basis of legitimacy of control over a territory or a plot of land called ulayat land. Ulayat Land is a plot of land that belongs to a group of people in a region. Although the customary law community has full customary authority to control, cultivate and utilize its ulayat land, but its formal juridical authority is not as strong as that of the State. The position of indigenous and tribal peoples is ultimately acknowledged conditional through various state regulations issued by the Government as in the Basic Agrarian Law Number 5 of 1960 Article 3. The conditional recognition that indigenous and tribal peoples can be recognized throughout 1) in reality Still exist, 2) in harmony with the times, 3) in accordance with national interests, 4) confirmed by local regulations. Such conditional recognition directly or has strengthened the State's domination of the rights possessed by society, it means that indigenous and tribal peoples will always be defeated when faced with state to defend their rights. The consequences of such an imbalance will clearly affect the role of indigenous and tribal peoples in the management and utilization of their ulayat land.
\end{abstract}

Keywords: ulayat right; customary law community

\section{INTRODUCTION}

In the community of customary law, the land is very special position, as a place to build a buildings, feeding places, where they are buried, have a spiritual value where they can relate to their ancestors. From a historical and cultural point of view, our society is an agrarian society, and to date even though industrialization has become the demands of society in the era of modernization, yet most Indonesians still use the land for the benefit of human life as a group. Efforts soil functions for the public benefit, including indigenous peoples can not be separated from the various considerations religious, social, and economical ${ }^{1}$. Many of

${ }^{1}$.Valerine J.L. Kreikhoff. (2003). Tinjauan Antropologi Mengenai Hak Masyarakat Adat Dan wewenang Negara, dalam Hukum Dan Kemajemukan Budaya, Sumbangan Karangan Untuk Menyambut Hari 
the changes that have been produced with their development in all fields starting from the changes to the structure and social institutions with all its aspects. This is due to the number of development activities in recent years developed by the government and private parties to increase the economic value of natural resources such as the development of housing for both occupancy and for commercial and business areas are increasing, especially in large cities and surrounding areas, the policy program population distribution through transmigration and resettlement programs which would require the land. Development in the forestry and mining sectors that would require land in a very wide area. In addition, in recent years the growth of property and housing business, especially in big cities and surrounding areas, has also spurred the rapidly increasing demand for land. ${ }^{2}$

Control of ideas and implementation of development by the state ultimately puts the people in a position opposite to the state $^{3}$, both in the meaning as a subject of

Ulang tahun ke 70 Prof. Dr.T.O. Ihromi. Jakarta: Yayasan Obor. pg. 174

2 Zakaria \& Soehendoro. (1995). Pengaturan Hukum Adat Tanah dalam Perundang-undangan Nasional dan Rasa Keadilan. Paper of National Seminar Pluralisme Hukum Pertanahan di Indonesia. Jakarta: YLBH, pg. 3

${ }^{3}$ Mahanani Subekti. (2001). Kedudukan UUPA 1960 dan Pengelolaan Sumber DayaAgraria di Tengah Kapitalisasi Negara (Politik Kebijakan Hukum Agraria development and as a victim of development that designed or established by the state. Do not be surprised if it happens land conflicts, especially between groups of people with the government as a ruler. Such conflicts have so far filled the long list of contents. The cases of land conflicts are almost all over Indonesia, in the islands of Sumatra, Java, Irian Jaya, Kalimantan, Sulawesi, even to small islands such as Kepulauan Seribu, Kepulauan Maluku, Mataram and East Nusa Tenggara.

Sometimes the government takes the land of the people with a reason for development. The land that the government considers to be ulayat land. The existence of ulayat land does not actually belong to a particular tribe, group or person or government. Thus the position of the community (adat) will obviously be very weak if the acts committed violently and ideologically are done. Sometimes parties to this conflict, both project managers in the field as well as local and central government, evade from the fact that the local indigenous people first possess the land and natural resources. Various cases of ulayat land arising on a regional or national scale, will never obtain a thorough completion

Melanggengkan Ketidakadilan). Jurnal Analisis Sosial, 6(2): 21 . 
without the necessary objective criteria as a benchmark for the existence of Ulayat Rights ${ }^{4}$.

According to Basuki Rekso Wibowo ${ }^{5}$ in practice is often a clash of substance and how the arrangement between the state law on the one hand with customary law and religious law on the other hand, due to the fundamental differences concerning the source of authority, the authority arranged, the substance of the rules, procedures, organization and goal setting which state law derived from the authority of the state authorities, are rendered through a formal mechanism and put in the form of formal rules in the form of legislation is "Top Down" while customary law derived from the authority of the authority of the community, its existence is due to the existence and development of society is "Bottom Up ".

Faced with the need for land in development activities that would require extensive land, customary land that has been dominated by indigenous peoples was also being taken to meet the needs of the development. Moreover, if the content of natural resources in and on ulayat land is

\footnotetext{
4 Maria Sumardjono. (2006) Kebijakan Pertanahan. Jakarta: Kompas Agustus 2006,pg. 67

${ }^{5}$ Basuki Rekso Wibowo. (2007). Hukum Adat \& Hukum Negara di Bidang Pertanahan, Sumber daya Alam \& Kewarisan:Perbandingan, Perbeturan \& Solusi. Malang: Pelatihan Mediator Tingkat Lanjut (Masyarakat Adat, Tokoh Agama, dan LSM)
}

considered vital to meet the needs of the livelihood of many people as contained in the basic concept of land control by the state in Indonesia contained in Article 33 paragraph 3 of the 1945 Constitution and various legislation - other legislation not to hesitate to take the land. In such a situation, the indigenous peoples do not immediately give the communal land which is controlled for generations to be converted, controlled and managed by the state in cooperation with other parties who have the capital. They argue that they have Ulayat Rights over the land long before Indonesia existed. The right to land in the overall view is a communal right, but still allows the control of land individually under various conditions and with the permission of the Chief Customary.

Although indigenous peoples have full customary authority to control, manage and utilize their ulayat lands, their legal jurisdiction is not as powerful as the state. The position of indigenous peoples and their right to ulayat land is actually acknowledged conditional through various laws of state issued by the government as in Article 3 of the Basic Agrarian Law No. 5 of 1960 which states:

"In view of the provisions of Articles 1 and 2, the exercise of the Ulayat Rights and similar rights of customary law communities, insofar as 
they still exist, shall be such that in accordance with the national and state interests, based on unity Nation and should not conflict with other laws and other regulations "

Article 3 of the Basic Agrarian Law implies a recognition that the indigenous peoples can be acknowledged as long as: 1) in reality still exist, 2) in harmony with the development of the time / century, 3 ) in accordance with national interests and 4) confirmed by local regulations.

Nevertheless, the recognition of indigenous peoples and their rights still does not vary much with the style of recognition made in the era of the Old Order and in the New Order era. Such conditional recognition actually indirectly or directly reinforces the state's dominance over the rights possessed by indigenous peoples. This means that indigenous peoples will always be defeated when facing the state to defend their rights.

In the dynamics of the meeting between the two imbalanced authorities, the study on the Ulayat Right of customary law community becomes very important to do. Such a clear study will make a meaningful contribution to finding ideal models in the management and utilization of a more just, more democratic and more prosperous land.

\section{METHOD}

This research is legal (legal research) because of legal science has a distinctive character ${ }^{6}$. Philip M. Hadjon found normative legal research and can not be qualified as qualitative research does not use quantitative analysis (statistics), it is distinguished on the nature and consequences of data analysis ${ }^{7}$.

According to Peter Mahmud Marzuki, legal research is not required any hypothesis, in legal research is also not known data term. Similarly, the term qualitative and quantitative analysis is not a term commonly in legal research ${ }^{8}$.

The method used in this study is the approach of legislation, the conceptual approach and case studies.

Legislation Approach

(Statute approach) is made by reviewing and analyzing in depth the various kinds of legislation, carried out by analyzing the provisions of law, especially with regard to communal land in the national land laws.

Conceptual Approach is made by reviewing and understanding the concepts of the laws relating to the rights of communities in the management and utilization of communal land.

\footnotetext{
${ }^{6}$ Philipus M. Hadjon dan Tatiek Sri Djamiati. (2005). Argumentasi Hukum, Gadjahb Mada University Press, ,pg. 1

${ }^{7}$ Ibid

${ }^{8}$ Peter Mahmud Marzuki. (2005). Penelitian Hukum. Jakarta: Kencana Prenada Media Group,pg. 36
} 
The case studies (case study) by exposing examples of cases of rights of community of the customary law.

\section{ANALYSIS AND DISCUSSION}

\section{Relationship Between Land With} Communities In Customary Law

The people of Indonesia depend on their livelihood, meaning that people's dependence on land is very high. Land for the community is considered very important. In terms of philosophy, the land is a symbol for the dignity of their lives. Tanah is a place of birth, place of life, place of worship and also a place to die. As a place of birth, every relative must have a house where posterity is born. As a place to live, every relative must have a rice field or field that is a mainstay to ensure the feeding of relatives. Land is made a place to worship, worship and to worship. As a place of death, every people should have a cemetery so that the body can be buried. The relationship between land and society above it will always be intertwined in various interests.

Land is something related to his predecessors, as land for indigenous peoples have a special and very important value in the livelihoods ${ }^{9}$. Customary Law

9 Djuhaendah Hasan. (1997). Rumah Vertikal Berdasarkan sistem Srata Title Suatu Alternatif Dalam penilaian Rumah oleh Orang Asing . Majalah Hukum Nasional, BPHN, No. 1.pg. 23. itself gives valuation and appreciation to the land in such a way that the land becomes a very special thing and gets special treatment in its legal arrangement.

These interests are looked at associations

law (rechtsgemeenschappen) illustrated by Faith Sudiyat as follows:

The local Guild (dorpsgemeenschap) or union territory (streekgemeenschap) is not only a legal union alone, but especially the business alliance, with the land as capital; A company in which all members of the partnership in question have and have their obligations and sources primarily obtain the possibility of fostering their livelihoods.

The legal partnership was also formulated by Ter Haar as "a regular, fixed gang with power of its own, also its own treasures of visible and invisible objects"10

From what has been pointed out above, it is recognized that not all circumstances in which there are people who live as a whole can be called legal partnerships. Only people who meet the elements:

10 B. Ter Haar translate by K. Ng. Soebekti Poesponoto. (1999). Azas-azas dan Susunan Hukum Adat, Jakarta: PradnyaParamitha, pg. 7 
1. Regularity

2. Live in one area

3. Have their own power

Have their own physical wealth, as well as spiritual, which is viewed as a unity of indigenous communion society.

From elements put forward clearly visible relationship between the land with indigenous and tribal peoples having the meaning that the land which is the wealth of the people residing within a certain area lives continuously has a solid unity and has the regularity of the customary law community, retained by its leader or adat leader. The existence of indigenous and tribal peoples existed before the United State of the Republic of Indonesia.

As social beings they certainly do not live alone but live together in groups. In that common life they organize themselves and other members of society according to the custom which is regarded as the legal order. The custom which is perpetuated in the end customary law is recognized through its adat institutions. Indigenous and tribal peoples will be subject to the rule of adat law. Indigenous and tribal peoples themselves are a group of people who live in a very strong brotherly ties based on heredity. In defending themselves they appoint one of them as a leader who has power which is limited to the region and to the society in which the leader is appointed.

The land for a customary law community is very important, given the close relationship between indigenous peoples and certain lands or territories commonly referred to as ulayat lands. The so-called land belonging to the customary law community has an understanding of the right of the customary law community to a certain area which is quite wide.

Indigenous People's relation to the land where they stand affects the various functions of the land for human life, namely as a place of trying to establish a place to live, a place to feed them, where they are buried and places various other social activities. Indigenous and tribal peoples' relationship with the land is a mastering relationship, not civil, meaning that they can occupy the land where they can master.

Ulayat is often defined as the area where customary law communities have the authority to live. The area in which they are and want to make it a place to have a material life (eating, drinking) as well as immaterial (spiritual), therefore such areas are also made into sacred territory so that every act of authority requires a magical act of religious. 
Beschikkingrecht or communal land under customary law in the hands of tribes / communities / villages. As for the entry into force according to Ter Haar is as follows ${ }^{11}$ :

\section{a. Applies inward}

1. The community of law / its members together may benefit from the land and the plants and wild animals that live on it.

2. Members of a tribe / legal community, for their own right to hunt, to collect forest products (which are then owned by property rights) and even have the right to possess several trees that grow wild when the tree is maintained by it.

3. They have the right to open the land with the knowledge of the head of the tribe / legal community. Land clearing with the knowledge of the head of the tribe / legal / rural community, is a legal act

\footnotetext{
11 Imam Soetiknjo. (1985). Undang-undang Pokok Agraria, Sekelumit Sejarah. Jakarta: Departemen Dalam Negeri. Direktorat Jenderal Agraria, pg. 45-47
}

that is protected by the legal community. The relation of rights between the person who clears the land and the open land, the longer the stronger if the land continues to be cultivated, and finally becomes the property of the opener. Nevertheless, the Ulayat right of the legal community over the land remains despite weakening. If the land has been opened it is then left untreated then the soil will be back into the land Ulayat rights law community village. Another of the important transactions that the land should be premises support (medewerking) c hieftain / communities / villages.

4. By the people of the law itself can be determined parts of the area that will be used for residential areas, places for tombs, general stocks, rice fields 
and other purposes

together.

b. Apply out

1. Members of other ethnic groups (also neighbors) should not take advantage of the land area of communal land, except with the permission of the head of the tribe / community law, and to give some small gifts (money income,

Aceh; mesi, Java)

first. Permission granted to other tribes is temporary, eg for one harvest season. In principle other members of other tribes can not have ownership rights over these lands.

2. A tribe / legal community with an Ulayat Right to its territory, is responsible for matters occurring within the territory. For example, if another member of the tribe is found dead or killed in the area, the tribe / local law community is responsible for finding the murderer or paying the fine.

When viewed from the validity of the Ulayat Right, it is clear that the communion of customary law has the characteristics or signs of the Ulayat Right namely:

1. Is the property of an individual or family member of an adat law community

2. Cannot be diverted or transferred

3. Applies only to local customary law communities

4. Outsiders or people from neighboring communities cannot control the land with private rights, may only collect the proceeds after obtaining permission from the public.

utilization of communal land after paying something (recognition) by outsiders.

Thus, indigenous and tribal peoples can control and use the land freely and in full accordance with the provisions applicable in the customary law community itself. The alien who seeks and collects the proceeds shall obtain the recognition and permission of the adat leaders or adulterers. 
Customary rights relations with indigenous and tribal peoples have a reciprocal relationship. The stronger the relationship between the community and the land the stronger the ulayat right holds. Conversely, if the relationship between the individual and his land is getting stronger, then the community's right to land is getting weaker

In indigenous and tribal peoples there is an authority to act with the intention of preserving the wealth of indigenous and tribal peoples, but the authority is not so great that it merely resembles the power to exclude the right of indigenous and tribal peoples to sell or relinquish their rights to non-indigenous peoples.

Thus the relationship between indigenous and tribal peoples with the soil contains various meaning which is strategic in society life like political aspect. Land is the basis for enlarging the territory of power in maintaining survival and the land as a force in the conduct of competition with groups that are at its borders. While as the economic aspect of the land is a symbol of prosperity and wealthy so it is regarded as an inheritance of ancestral heritage that cannot be transferred to anyone except their own offspring. Viewed from the socio-cultural aspects of the land is a refuge and the life of the ancestral spirits as the predecessor who controlled the region in the form of magical nature as a protector and keep the fertility of his ancestral land.

\section{Implementation of Protection Of The} Legal Rights Of Indigenous Peoples

After waiting for 55 years before 2000 the second amendment was made to the 1945 Constitution. The amendment to the 1945 Constitution carries the consequences of the interpretation of the recognition of the existence of the Community of Customary Law and their rights as regulated in Article 18B paragraph (2) which reads:

"The State recognizes and
respects the unity of
indigenous and tribal peoples
along with their traditional
rights as long as they are
alive and in accordance with
the development of society
and the principle of the
Unitary State of the Republic
of Indonesia. "

And Article 28 I Paragraph (3) which reads:

"The cultural identity and
rights of traditional societies
are respected in harmony
with the times and
civilizations"

Both of these articles still use the concept of "conditional recognition" as embraced by various laws on Natural 
Resources (SDA) derived from Article 33 paragraph (3). Given the principles of the rules governing the "earth, water, and natural resources contained therein are controlled by the state, it is hardly possible for indigenous and tribal peoples to easily acquire the ruler. This may be due to the role of the State to recognize the existence of indigenous and tribal peoples insofar as these customary laws conform to state regulations.

The recognition of indigenous and tribal peoples in the 1945 Constitution creates a very dilemmatic issue, one side being the spirit of recognition to protect the legal community and its rights, but on the other hand the state has a very big role so that it is more concerned with the interests of the State not the interests of indigenous people. Budi Hardiman suggests pleased to Article 18B (2) and Article 28, first paragraph (3) illustrates that the state has a major role in defining, recognizing and legitimizing the existence of indigenous and tribal peoples throughout the country in accordance with a rules. This paradigm is incompatible with the principles of equality and democratic autonomy.

If we look at the contents of Article 18B paragraph (2) and Article 28 I paragraph (3), it appears that there are two laws regulating indigenous peoples. On the one hand Article 18B Paragraph (2), recognition of the existence or existence of customary law communities shall enter into the domain of laws relating to local government, whereas the Law 28 I Paragraph (3) shall be regulated in the Law on Human Rights.

However, the existence of Article 18B Paragraph (2) of the 1945 Constitution has already appeared to be good for the practice of protection of indigenous and tribal peoples (hak ulayat). With the existence of this article means that there is already a strong constitutional foundation for indigenous and tribal peoples whose traditional rights have been neglected.

In its development, recognition that supports the existence of Indigenous People and their traditional rights. Acknowledgment and respect for Ulayat Rights are contained in various Regulations including Regional Regulations (PERDA) which use the legal basis relating to the authority of the regional regulation as well as the legal basis relating to the material set forth in the law. Examples of several Regions governing the recognition and respect of Ulayat Rights are the Regional Regulations of Kampar Regency Number 12 Year 1999 on Ulayat Rights; Regional Regulation of Lebak Regency Number 32 Year 2001 
concerning the Protection of the Ulayat Right of Baduy People; West Sumatra Regional Regulation No, 6 Year 2008 on Ulayat Land. And some areas are drafting the Local Regulation of Tobelo Civil Rights Right, the Draft of the Local Regulation of Ulayat Rights of Halmahera Utara and Article 6 of Law N0. 39 In 1999 on human rights. In the reform era the opportunities to provide protection to indigenous and tribal peoples (Ulayat Right) are beginning to appear. The protection of indigenous and tribal peoples other than those mentioned in Article 18B paragraph (2) and Article 28 I Paragraph (3) of the Second Amendment Act of 1945 of 2000, is also stated in Article 41 of MPR Decree Number XVII / MPR / 1998 on Human Rights, MPR Decree No.IXMPR / 2001 on Agrarian Reform and Natural Resources Management, Article 5 paragraph (3), Article 6 paragraph (1) and Article 6 paragraph (2), Law no. 39 of 1999 on Human Rights, Regulation of the State Minister / Head of BPN No. 5 of 1999 concerning the Guidance on the Settlement of Problems of Customary Communities Community Customary Rights. However, recognition of the legal community as well as traditional rights is not necessarily followed up. This is because the current national positive legal system does not provide a legal status to indigenous and tribal peoples with a variety of policies, regulations and decisions that certainly limit the existence of indigenous and tribal peoples.

The consequences of all this arise conflicts in various regions of the homeland relating to ulayat land. These conflicts arise notwithstanding that indigenous and tribal peoples wish to retain their ulayat rights resulting in conflict with the Government, investors who have obtained various forms of licensing to use or exploit customary community land.

Developments that support the recognition of indigenous and tribal peoples and their traditional rights continue. Expert Forum Meeting of KAT (Remote Indigenous Communities) ${ }^{12}$ April 2, 2009, discusses the multiyear approach in the KAT empowerment needs to be reconsidered as a process of continual change for KAT.

At the international level juridical recognition of indigenous and tribal peoples is contained in the ILO Convention no. 169 of 1989 on The indigenous and Tribal Peoples in Independent Countries (indigenous and

12 Pertemuan Forum Pakar Pemberdayaan KAT. (2009). Artikel Departemen Sosial. Jakarta 
tribal peoples in independent countries) defines indigenous peoples as tribes who resided in independent countries whose social, cultural, and economic, which is different Other society. In general, the ILO Convention recognizes that indigenous and tribal peoples are recognized and guaranteed their right to self-determinate their various priorities in the development process affecting their lives, beliefs, institutions and well-being and the lands and territories (ulayat) that They have to be protected, or the rights of the peoples concerned to use lands that are not exclusively occupied by them, but traditionally they have access to their livelihoods and traditional activities, and to exercise control over, until Possible limits, on their economic, social and cultural development.

However, despite the legal protection of indigenous people in various legislation, there is still a lot of oppression on customary law community rights committed by the Government and investors. This is because the protection of the Ulayat Right of customary law community still adheres to conditional recognition. So that there are irregularities to the legislation that should provide protection.
Recognition of an Adat Law by State Law also brings the issue of legal certainty. Understanding the principle of legal certainty in Customary Law is not the same as the legal certainty principle understood in the legal system of the state, other things with the recognition of state law against custom written law system, such as Islamic law, Christian law, Hindu law that usually does not cause problems The legal certainty as evoked by the recognition of state law on the unwritten system of Customary Law.

\section{CONCLUSION}

Basically, indigenous people have a very close relationship with their ulayat land, especially regarding the pattern of mastery and utilization. Initially it must be admitted that indigenous peoples have authority that may be said to be very autonomous and absolute in the control and utilization of ulayat land and various agrarian resources residing in it. However, over time and the strengthening of the role of the state in various fields, the role of indigenous peoples in their development has faced many challenges and has weakened in the presence of the state. The strengthening of the role of the state is strengthened by the entry of the concept of "Right to Control the Country". Which is constitutionally based on Article 33 Paragraph (3) of the 
1945 Constitution and is the basis of control of the state, as well as various positive laws under it such as BAL and other positive laws enacted after the LoGA.

Basically, the customary law community has full customary authority for the control and utilization or management of its ulayat land, but the formal jurisdiction of its authority is not as strong as the state as stipulated in the LoGA. The position of indigenous peoples and their right to ulayat land is actually acknowledged on a conditional basis through various laws of the state issued by the Government as in Article 3. It is hoped that there will be a pattern set forth in the legal provisions governing the utilization and management of communal land that is carried out collaboratively between the state and the legal community Adat, so that the existing role of customary law community on Ulayat Rights is balanced with the role that exists in the State especially to the Regional Government. Therefore, it is necessary to divide the authority between the central and regional governments that directly touch on the ulayat right of customary law community. Indigenous and tribal peoples are given the opportunity to build better relations with the State as well as the investors in the management of natural resources within its ulayat territory. Thus creating a balance in the utilization and management of agrarian resources / natural resources for the welfare of the people. With this pattern it will give recognition to customary rights for indigenous and tribal peoples in management involving investors / owners of capital with due regard to the existence of customary law community over ulayat land.

\section{BIBLIOGRAPHY}

Basuki Rekso Wibowo.(2007). Hukum Adat \& Hukum Negara di Bidang Pertanahan, Sumber daya Alam \& Kewarisan : Perbandingan, Perbeturan \& Solusi.Batu-Malang. Pelatihan Mediator Tingkat Lanjut (Masyarakat Adat, Tokoh Agama, dan LSM).

Djuhaendah Hasan.(1997). Rumah Vertikal Berdasarkan sitem Srata Title Suatu Alternatif Dalam penilaian Rumah oleh Orang Asing".Majalah Hukum Nasional, BPHN. No. 1.

Mahanani Subekti. (2001). Kedudukan UUPA 1960 dan Pengelolaan Sumber Daya Agraria di Tengah Kapitalisasi Negara (Politik Kebijakan Hukum Agraria Melanggengkan ketidakadilan). Jurnal Analisis Sosial, 6 (2): 21.

Marzuki Mahmud Peter. (2005). Penelitian Hukum. Jakarta: Kencana Prenada Media Group.

Philipus M Hadjon dan Tatiek Sri Djamiati. (2005). Argumentasi Hukum. Gadjah Mada, University Press. 
Sumardjono Maria S.W. (2001). Kebijakan Pertanahan Antara Regulasi Dan Implementasinya. Kompas.

Sumardjono Maria S.W. (2008). Tanah Dalam Perspektif Hak Ekonomi Sosial dan Budaya.Kompas.

Ter Haar Bzn Translate by K Ng Soebakti Poesponoto, (1960). Azas-azas dan Susunan Hukum adat. Jakarta: Pradnya Paramita.

Valerine J.L. Kreikhoff. (2003). Tinjauan Antropologi Mengenai Hak Masyarakat Adat Dan wewenang Negara, dalam Hukum Dan Kemajemukan Budaya, Sumbangan Karangan Untuk Menyambut Hai Ulang tahun ke 70 Prof. Dr.T.O. Ihromi. Jakarta: Yayasan Obor.

Zakarias, R. Yando \& Soehendoro, Djaka. (1995). Pengaturan Hukum Adat dalam Perundang-undsangan Nasional dan Rasa Keadilan. Paper of National Seminar Pluralisme Hukum Pertanahan di Indonesia. Jakarta: YLBHI. 